


\title{
Yksi identiteetti monesta peilistä - kanttorin ammatillisen identiteetin ytimessä
}

\author{
Lectio praecursoria
}

\begin{abstract}
Anna Heleniuksen väitöskirja tarkastettiin 7.3.2021 Taideyliopiston Sibelius-Akatemian Rtalon kamarimusiikkisalissa. Väitöskirjan nimi: Yksi työ ja kymmenen tekijää - Suomen evankelis-luterilaisen kirkon kanttoreiden kokemuksia omasta ammatillisesta identiteetistään. Vastaväittäjänä toimi yliopistonlehtori KT Susanna Paloniemi, Jyväskylän yliopisto. Kustoksena oli professori MuT Tuire Kuusi, Taideyliopiston Sibelius-Akatemia.
\end{abstract}

\section{YKSI IDENTITEETTI MONTA PEILIÄ- KANTTORIN AMMATILLISEN IDENTITEETIN YTIMESSÄ}

Kysymykset "kuka minä olen" ja "keitä me olemme?" johdattavat identiteetin ilmiöön. Identiteetti on ihmisen yksilöllinen käsitys itsestään, ja siihen vääjäämättä liittyy myös valinta ja vertailu siitä "kuka minä en ole?" Identiteetti nivoo yhteen yksilöllisen elämänhistorian, nykyhetken ja myös käsityksen tulevaisuudesta, eli siitä, "millaiseksi minä haluan tulla?" Yhteiskunnassamme vallalla oleva yksilöllisyyden ihannointi nostaa identiteetin kysymystä pohdintaamme yhä useammin. Myös työelämässä, mukaan lukien Suomen evankelis-luterilaisen kirkon työelämä, työntekijän tulee osata jäsentää ammatillisuutensa.

Ajatus tutkimukseeni lähti havainnoistani, että me kanttorit olemme kukin hyvin erilaisia ja ajattelemme työtämme eri tavoin. Tämä huomio herätti kiinnostukseni tutkia asiaa syvemmin. Tutkimukseni kohteena ovat kanttoreiden kokemukset omasta ammatillisesta identiteetistään. Tätä identiteettiä peilataan vuorovaikutuksessa muun muassa muiden kanttoreiden kanssa ja muiden työyhteisön jäsenten tai seurakuntalaisten kanssa. Muistissa ovat myös lukuisat vuorovaikutustilanteet elämän varrelta erimerkiksi soitonopettajan kanssa, muiden opiskelijoiden kanssa ja niin edelleen. Oma kuva heijastuu peilistä, sosiaalisessa todellisuudessa peileinä toimivat vuorovaikutustilanteet.

Ammatillisen identiteetin elementtejä ovat yksilöllinen elämänhistoria, menneet odotukset ammatilta, opiskeluaika, käsitys omasta ammattitaidosta, samastumiset ja sitoutumiset, motivaatio ja käsitys tulevaisuudesta. Erityisesti luovissa ammateissa, 
kuten kanttorin ammatti, myös omalla persoonalla on osansa ammatillisessa identiteetissä. (Eteläpelto ja Vähäsantanen 2010, 26, 43-44.)

Ymmärrys kanttoreiden identiteetistä on tähän saakka ollut arkikäsitysten ja perinnetiedon varassa. Kanttoreista on käytetty urheilutermejä moniottelija tai kymmenottelija, ja kanttorin ammattia on kuvattu maailman monipuolisimmaksi ammatiksi - sisältäähän työ koko elämän kirjon; vauvamuskareista hautajaisiin, lehti-ilmoituksen laatimisesta somepäivityksiin, suunnittelusta käytäntöön, pianon ostosta tilinpäätökseen, verkkareista frakkiin ja laulusta soittamiseen. Sitä paitsi yksi kanttorin soittimista on urut. Soitin, joka jo yksin omassa monipuolisuudessaan vetää vertoja mille tahansa muulle soittimelle. Sitä soitetaan jokaisella sormella ja molemmilla jaloilla, sekä kannalla että kärjellä, monesti vielä samanaikaisesti laulaen. Levinnein arkikäsitys lienee se, että kanttoreilla on kaksi identiteettiä, sekä muusikon että kirkon työntekijän identiteetti, tai että kanttori itse valitsee itselleen toisen näistä identiteeteistä. Perinnetiedon mukaan kanttori puolestaan on henkilö, joka muun muassa on vähän uskonnollinen ja vähän musikaalinen.

Mihin ammatillista identiteettiä sitten tarvitaan erityisesti kanttorin työssä? Käsitys siitä, kuka olen ja mihin kuulun, on toki ratkaisevan tärkeä ammatissa kuin ammatissa. Kirkon akateemisten jäsenkyselyn vuodelta 2018 mukaan suurin osa kanttoreista on työhönsä tyytyväisiä, mutta työhönsä tyytymättömien kanttoreiden osuus on neljässä vuodessa lähes kaksinkertaistunut. Samoin kanttoreiden työssä uupuminen on huomattavasti lisääntynyt. (Tervo-Niemelä 2018, 55.) Tyytymättömyys työssä tarkoittaa yksinkertaistettuna sitä, että työ ja työntekijän käsitys työstään eivät vastaa toisiaan. Esimerkiksi tällaisessa tilanteessa ammatillisen identiteetin pohdinta tukee työntekijän toimijuutta ja mahdollisuuksia vaikuttaa työhönsä. Selkeä käsitys omasta ammatillisesta identiteetistä helpottaa sekä henkisten että rakenteellisten rajojen asettamista työssä. Kanttorin, moniottelijan ammatissa jos missä, kiinnittyminen edes oman identiteettinsä ankkuriin edesauttaa selviytymistä toiveitten ja odotusten keskellä työelämässä.

Käsillä olevassa tutkimuksessani asetin tutkimuskysymykseni seuraavasti: Millaisena kanttori kokee oman ammatillisen identiteettinsä? Tämän tutkimuskysymyksen esitin aineistolle, joka muodostui kymmenen kanttorin haastattelusta. Nämä kymmenen työskentelivät eri puolilla Suomea ja joukossa oli sekä seurakuntansa ainoita kanttoreita että usean kanttorin seurakunnassa työskenteleviä. Kaikilla haastatelluilla oli työkokemusta vähintään kymmenen vuotta. Tutkimuskysymystäni tarkensi kaksi alakysymystä: mitä ammatillisuuden elementtejä aineistosta paljastuu ja mitä työpaikan toimintaympäristön elementtejä aineistosta paljastuu? Analysoin tekstimuotoon litteroitua aineistoa ensin aineistovetoisesti teemoittain ja myöhemmin teorian ohjaamana.

Haastattelemani kanttorit olivat tavallisesti aloittaneet musiikin harrastuksena jo varhain lapsuudessa, useimmat pianonsoitolla. Kotiseurakunnan kanttorilla oli usein jokin rooli kanttoreiden urapolun alussa. Opiskeluaikaa haastatellut kuvasivat 
harjoittelun täyteisenä, joka edellytti sinnikkyyttä. Oman osaamisen vertailu toisiin opiskelijoihin oli ollut myös tavallista. Vaikka haastatellut kertoivat tehneensä paljon kanttorin sijaisuuksia opiskeluaikana, ei käsitys työstä lopulta vastannut todellista kuvaa viranhoidosta. Erityisesti kanttoreita yllätti seurakuntakuoron heikko taso, surevien kohtaaminen ja hallinnollisten tehtävien sekä kevyen musiikin paljous työssä. Moni koki, että musiikilliset taidot urkujensoitossa tai laulussa olivat pidemmällä, kuin mitä seurakunnassa odotettiin.

Kymmenen haastattelemaani kanttoria lähestyivät identiteettiään osaamisensa kautta. He jäsensivät tarkalleen sen, miten taitavia he minkäkin instrumentin hallinnassa olivat. Aivan yhtä - tai ehkäpä jopa vielä tarkemmin haastatellut jäsensivät sen, mitä he eivät osaa. Moni koki, että tarvitsisi työssään vielä useamman instrumentin hallintaa; esimerkiksi kitaran tai huilun. Riittämättömyyden tunne piinasi siitäkin huolimatta, että osaamista oli paljon. Lähimmäksi koettu instrumentti oli tavallisesti se, jonka opinnot oli viety pisimmälle. Kaikki kanttorit identifioituivat työssään hengelliseen musiikkiin.

Kanttorit kertoivat sitoutuvansa työssään asialliseen pukeutumiseen aina tilanteen vaatimalla tavalla. Naiskanttorit kiinnittivät huomiota $\mathrm{mm}$. helman pituuteen. Kanttorit kertoivat myös saavansa palautetta pukeutumisestaan seurakuntalaisilta. Haastatellut olivat sitoutuneita myös korkeatasoisuuteen. He pyrkivät työssään nöyrästi korkeaan laatuun ja olivat tottuneet tekemään töitä sen eteen. Edelleen työelämässä omaa osaamista saatettiin vertailla toisiin kanttoreihin, vertailua tekivät myös seurakuntalaiset. Kanttorit suhtautuvat kriittisesti omaan musisointiinsa. $\mathrm{He}$ halusivat harjoitella, ja mikäli siihen ei ollut aikaa työpäivinä, sitä tehtiin vapaalla. Osa haastatelluista koki rutiinin hyväksi ja työtä helpottavaksi seikaksi, osa koki sen uhkaksi herkkyyden menettämiseen. Kriittisyyden rinnalla työvuosien tuomana myös armollinen suhtautuminen omaan tekemiseen oli pilkahtanut muutaman haastatellun mieleen.

Kanttorit olivat työssään sitoutuneet työajattomaan työhön, osalle työ oli elämäntapa ja kaikille jonkinlainen kutsumus. He kokivat tarvetta vaalia ja varjella vapaapäiviään. Erityistä ristiriitaa aiheutti perhearvojen sovittaminen työn vaateisiin. Haastatellut kohtasivat paljon odotuksia työyhteisön sisältä, esimerkiksi pyyntöjä tulla tekemään työtovereiden toivomaa työtä. Näissä pyynnöissä kanttorit kipuilivat esimerkiksi oman vapaa-aikansa kanssa.

Haastatellut kokivat motivoituvansa työssään esimerkiksi musiikista, harjoittelusta ja konserteista, kuorotyöstä ja seurakuntalaisista. Asiat, jotka motivoivat yhtä, saattoivat turhauttaa toista, kuten seurakunnan resurssit tai työvälineet. Turhautumista aiheutti myös jatkuva työn puolustaminen työyhteisössä, väärät käsitykset kanttorin työstä ja monenlaiset epäselvyydet. Monipuolinen työ sekä motivoi että turhautti, samoin työn itsenäisyys. Tuloksista on pääteltävissä, että motivoituminen suuntautui arvojen mukaan. Siitä, mitä pidettiin arvossa, myös motivoiduttiin. 
Kanttorit ajattelivat tulevaisuudessa tarvitsevansa lisäkoulutusta ja halusivat kehittää työtään mielekkäämpään suuntaan. Haastatellut kertoivat kulkeneensa pitkän ja haastavan tien musiikin opintojen parissa, tuo aika oli vaatinut myös uhrauksia. Tämä satsaus ja panostus oli monelle syynä siihen, ettei ammattia haluttu vaihtaa, jos ja kun sellainen ajatus mieleen tuli. Kanttoreita huoletti ulkopuolisen muutoksen ja kirkosta eroamisen vaikutus työhön. Eläkeikää he eivät olleet vielä miettineet ja suhtautuivat siihen kaukaisena asiana.

Keskeisenä seikkana kanttoreiden ammatillisen identiteetin kokemuksessa olivat arvot. Ne ohjasivat kiinnostuksen ja motivaation kohteita. Tärkeimmät arvot kanttoreille olivat kristillisyys ja siitä seuraava kohtaamisen arvo sekä musiikki ja siitä seuraava korkeatasoisuuden arvo. Tuloksista voi päätellä, että seurakuntatyöyhteisössä vain kanttorit liittävät työnsä arvoihin musiikin. Musiikin vaateet voivat olla työyhteisölle vieraita ja aiheuttaa ristiriitoja.

Vaikka huomattavaa on, ettei tutkimukseni tulokset ole laajasti yleistettävissä, on yksittäisyydessä aina jotain yleistä. Selvää lienee, että kanttorin ammatin ammattilaisia ja asiantuntijoita ovat kanttorit itse. Tämä tutkimus antaa heille äänen. Tuloksissa kuuluu kaikuja siitä, että kanttorin työhön liittyviä päätöksiä tekevät usein jotkut muut. Tämä tutkimus osoitti muun muassa sen, miten vähän kanttoreilla todellisuudessa on mahdollisuutta vaikuttaa omaa työhönsä. Työ saattaa vaikuttaa rakenteettomalta ja jäsentymättömältä. Erilaiset työtehtävät, työn alueet ja seurakunnan sisäiset yhteistyön muodot täyttävät päiviä. Ihailtavana työn ominaisuutena pidetty itsenäisyys on osittain totta, mutta se onkin ohuempi juonne kuin oletamme. Samoin tämä tutkimus osoitti kanttoreiden kohtaavan erityisen paljon odotuksia työyhteisöltä, ja he kokivat työyhteisön puuttumisen usein liiallisena. Eräs haastateltu pohtikin työtään kysyen "missä se musiikki enää oikein on?” Oman työn fokus, musiikki, on vaarassa jäädä sivuun ja ulkokehälle kaikelta muulta. Toki tätä voidaan pitää myös positiivisena seikkana - kanttorille on aina kysyntää.

Riittämättömyyden kokemus lienee juontuvan rajojen puutteesta. Haastateltujen mukaan kanttorin pitäisi pystyä itse rajaamaan työtään, jotta musiikki olisi työn keskiössä. Vain yksi haastateltu kertoi oman esimiehen pyrkivän asettamaan työhön rajoja. Raja, se mihin jokin loppuu ja jokin toinen alkaa, on oleellinen seikka identiteetissä. Se ilmentää juuri sitä valintaa, kuka minä olen ja kuka en ole.

Tämä tutkimus antaa työnantajalle, Suomen evankelis-luterilaiselle kirkolle konkreettista tietoa siitä, millaisena työ kanttoreille itselleen näyttäytyy. Samoin tutkimuksen tuloksista, erityisesti osaamisen kokemuksista voi hyötyä kanttoreita kouluttavat tahot. Näiden lisäksi ennen kaikkia toivon, että kanttorit itse hyötyisivät tutkimukseni tuloksista. Jokaisella ammatillisella toimijalla on ammatillinen identiteetti, oli hän pohtinut sitä tietoisesti tai ei. Vaikeasti tiedostettavan ilmiön tarkastelu on luonnollisesti haastavaa. Tämä tutkimus toimii kanttoreille eräänlaisena kaksiosaisena käsikirjana oman ammatillisen identiteettinsä tarkastelulle. Ensinnäkin se tarjoaa kuvauksen ilmiöstä itsestään teoreettisella tasolla ja toisek- 
TRIO vsk. 10 nro 1 - Lectiones praecursoriae: Anna Helenius 74-78

si kymmenen kanttorin haastattelupuheesta muodostuvan keskustelukumppanin. Tämän keskustelun toivon vahvistavan kanttoreita omassa ammatillisuuden kokemuksessaan.

\section{LÄHTEET}

Eteläpelto, Anneli ja Katja Vähäsantanen 2010. Ammatillinen identiteetti persoonallisena ja sosiaalisena konstruktiona. Teoksessa Anneli Eteläpelto ja Jussi Onnismaa, Ammatillisuus ja ammatillinen kasvu, 26-49. Vantaa: Kansanvalistusseura.

Tervo-Niemelä, Kati 2018. Kutsumuksen imu ja työn todellisuus. Pappien, teologien ja kanttoreiden subde työbön, työhyvinvointiin ja subtautuminen ajankobtaisiin kysymyksiin Kirkon akateemisten jäsentutkimuksessa 2018. Sakasti. Kirkon tutkimuskeskuksen verkkojulkaisuja. http://sakasti.evl.fi/julkaisut.nsf/81BBB4DEE8481DE4C22583200034A744/\$FILE/Kutsumuksen_imu_ja_tyon_todellisuus_18_10_02_verkko.pdf 